\title{
MAJOR ELEMENT CHEMISTRY OF METAMORPHIC AND GRANITIC ROCKS OF THE YANAI DISTRICT IN THE RYŌKE BELT
}

\author{
HiRoji HoNMA \\ Institute for Thermal Spring Research, Okayama University, Misasa, Tottori Pref., Japan
}

\section{INTRODUGTION}

Iwao (1936) was the first to have done a petrological investigation on the Ryōke metamorphic and granitic rocks at the Yanai district. Okamura (1957), with a detailed structural petrology and based on the concept of "granite series" by Read (1949), divided the Ryōke granitic rocks of this district into two groups, namely the older autochthonous and parautochtonous granites and the younger intrusive ones. He concluded that the thermal metamorphism was accompanied by the introduction of alkali-alumina emanations and produced the progressive metamorphic series: biotite schist - banded gneiss - migmatite - granite. Nureki (1960) described structural features of various scale of the Ryoke metamorphic rocks in this district and discussed the metamorphic history of these rocks.

As mentioned above, several detailed petrological and structural investigations on the rocks of this district have been done, however, the chemical studies on these rocks are scarce. Thirty-two whole-rock samples are analyzed chemically for the first step of the present writer's geochemical, mainly oxygen isotopic, investigation of the meta- morphic and granitic rocks of this district and the results are presented in this paper.

The analytical procedure here adopted is based on the systematic method proposed by Oki et al. (1962) using an ion exchange column. Alkalies are separated from each other and determined volumetrically. $\mathrm{H}_{2} \mathrm{O}^{+}$ is calculated from the weight loss by ignition.

\section{Geological Setting}

The original rocks of the metamorphic rocks are composed mainly of slate, sandstone and banded chert of the Kuga group (Kojima, 1953). The Kuga group had been regarded as Paleozoic in age, however, Toyohara (1974) recently found many fossils from this group which indicate Triassic age. $\mathrm{K}-\mathrm{Ar}$ and $\mathrm{Rb}-\mathrm{Sr}$ age determinations indicate the Ryōke metamorphism and plutonism occurred at upper Cretaceous (reviewed by Nozawa, 1970), while Kojima and Okamura (1968) suggested a possibility of existence of a pre-Ryōke plutono-metamorphism for a composite mass of granite gneiss and basic gneiss in this district.

A schematic geology of this district is shown in Figure 1 with the sampling points.

(Manuscript received, December 18, 1973) 

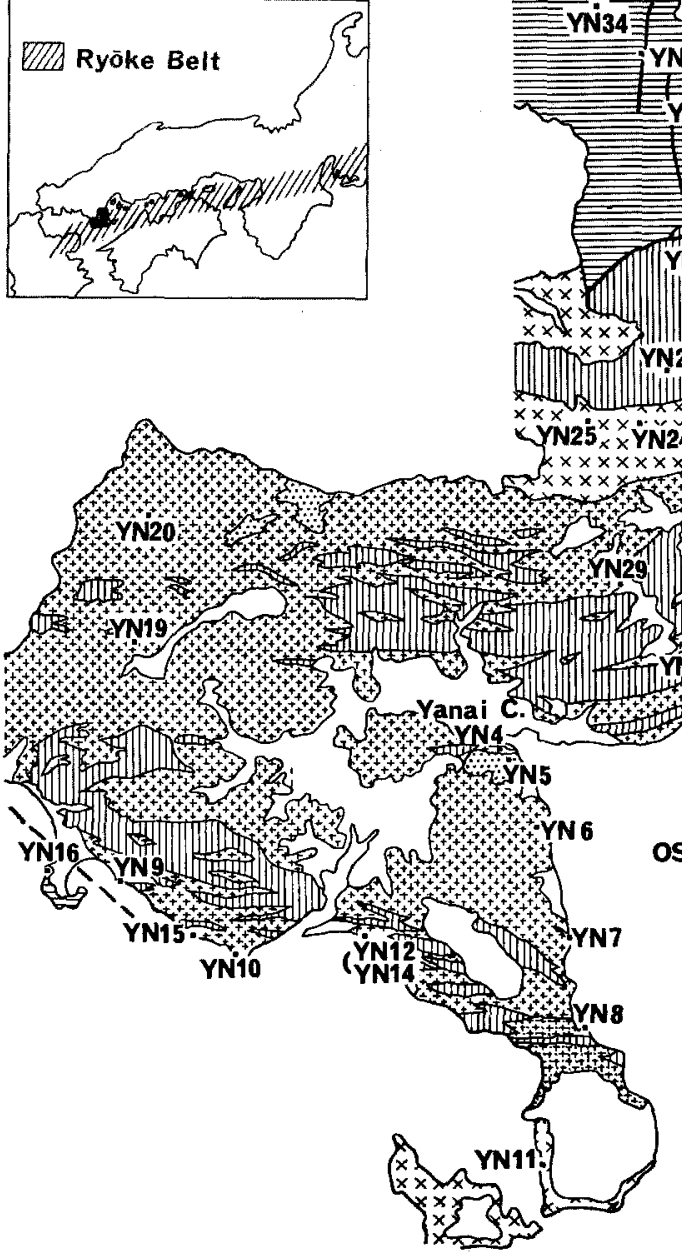

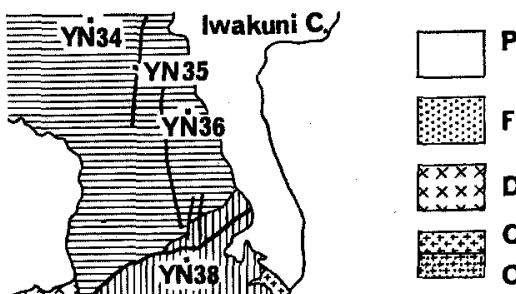
Post-Ryōke granites,
volcanics and sediments

Fine-grained granite

Discordant granite

Obatake-Gamano I. gd.

Okiura I. granite

Schistose hornfels

Gneiss

Fau It

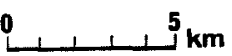

Figure 1. Map showing schematic geology of the Yanai district (after Okamura and Nureki, 1962) and localities of samples. Those samples that are not examined in this paper are also included for the convenience of referring with subsequent papers.

The marginal metamorphics (the zone of schistose hornfels and the zone of transitional rocks of Nureki, 1960) are distributed mainly in the northern part of the area, the metamorphic grade of which successively declines northwards in a short distance from sillimanite bearing gneiss through cordierite-K-feldspar gneiss and andalusite-spotted hornfels to biotite hornfels in the case of pelitic sediments. Garnet porphyroblasts occur in some siliceous metamorphic rocks.

The central part of the area (the zone of migmatite of Nureki, 1960) is occupied by the gneiss and granite complex consisted mainly of syntectic layered granitic rocks (the older autochthonous and parautochthonous granodiorites by Okamura, 1957) and siliceous banded gneiss with subordinate pelitic gneiss and amphibolite. The mineral paragenesis in each kind of metamorphic rock (pelitic, siliceous and basic 
metamorphic rocks) is rather uniform allover this complex and sillimanite occurs widely in pelitic gneiss, ocasionally growing as large as $20 \times 6 \times 4 \mathrm{~mm}$. Migmatitic rocks are widely distributed in this complex and detailed description of the petrological and structural evidence suggesting granitization of gneisses and amphibolite is presented in Okamura (1957, 1960). The syntectic layered (after Kojima and Okamura, 1968) granitic rocks which include the Ōbatake, Gokenya, Gamano and Okiura gneissic granodiorites of Okamura (1957) are named as the Gamano layered granodiorite as a whole by Kojima and Okamura (1968). All of them are characterized by intimate association with sedimentary gneisses. In this paper, they are divided temporarily into two groups named for convenience's sake as follows: The Ōbatake and Gamano layered granodiorites which correspond to the Öbatake and Gamano gneissic granodiorites of Okamura (1957) and the Okiura layered granite which corresponds to the Okiura gneissic granodiorite of Okamura (1957). The granite gneiss of Kojima and Okamura (1968) (0S10-2) and the Gokenya gneissic granodiorite of Okamura (1957) ( $\mathrm{YN} 10$ ) are included in the former granodiorites. A coarse-grained, garnet-bearing leucogranite (YN15) also is included in this group because of its intimate association with these layered granodiorites.

Three bodies of rather homogeneous and massive granites (the younger Tōwa, Murotsu and Kibe granites of Okamura, 1957) and many small bodies of fine-grained leucogranite intruded discordantly into the members of the complex mentioned above.

\section{Results AND DisGussion}

The analytical data are presented in Table 1 with a brief description of the analyzed specimens in Appendix. Following diagrams contain also three analyses of the discordant granites in this district by Shibata et al. (1960).

The variation diagram The variation diagram of the principal major elements, $\mathrm{K}_{2} \mathrm{O}$ / $\mathrm{Na}_{2} \mathrm{O}$ and $\mathrm{K}_{2} \mathrm{O} / \mathrm{CaO}$ is shown in Figure 2, where the siliceous gneiss and associated migmatitic granites are excluded because of their extraordinarily high silica-content.

The trend of the average Japanese granitic rocks (Taneda, 1962) is shown also in Fig. 2 for comparison. The variation of the rocks in this district excluding some amphibolites and pelitic gneisses may also be represented as a whole by this average trend.

$\mathrm{K}_{2} \mathrm{O}, \mathrm{Na}_{2} \mathrm{O}, \mathrm{MgO}$ and $\mathrm{CaO}$ in granoblastic amphibolites (OS8-2, OS7-1, OS11) vary significantly regardless in $\mathrm{SiO}_{2}$-content. An amphibolite (YN3-1), intermediate chemically between the agmatitic amphibolites and the Ōbatake and Gamano layered granodiorites, is plotted well on the curve for the average Japanese granitic rocks.

Pelitic metamorphic rocks are remarkably higher in $\mathrm{K}_{2} \mathrm{O} / \mathrm{CaO}$ than granitic rocks.

The coarse-grained granodiorites which represent the main facies of the Obatake and Gamano layered granodiorites are restricted in a narrow range of $\mathrm{SiO}_{2}$-content lower than 68 per cent. The rocks of this group carrying more $\mathrm{SiO}_{2}$ are as follows: a porphyroblastic quartz-bearing facies (OS72), a porphyroblastic K-feldspar-bearing facies (YN3-3) and a coarse-grained, garnet-bearing leucogranite (YN15). In spite of the high $\mathrm{SiO}_{2}$-content in OS7-2, the distribution of the other major elements is 
Table 1. Chemical Composition of Rocks

Analysts: K. Ikehara and H. Fukui

\begin{tabular}{|c|c|c|c|c|c|c|c|c|c|c|c|c|c|c|c|c|}
\hline No. & 1 & 2 & 3 & 4 & 5 & 6 & 7 & 8 & 9 & 10 & 11 & 12 & 13 & 14 & 15 & 16 \\
\hline Specimen & Os $2-4$ & YN 16 & YN 38 & YN 28 & os $2-1$ & OS 8-2 & OS 7-1 & OS 11 & YN3-1 & OS 1 & OS 8-1 & YN 10 & YN 3-2 & OS $10-2$ & YN 30 & YN 9-1 \\
\hline $\mathrm{SiO}_{2}$ & 93.15 & 66.57 & 61.46 & 62.67 & 66.11 & 49.63 & 50.60 & 51.80 & 55.59 & 62.83 & 64.98 & 65.04 & 66.38 & 63.25 & 65.60 & 65.86 \\
\hline $\mathrm{TiO}_{2}$ & 0.18 & 0.75 & 0.85 & 1.03 & 0.70 & 1.53 & 1.80 & 1.38 & 1.22 & 1.15 & 0.56 & 1.20 & 0.53 & 0.65 & 0.80 & 0.06 \\
\hline $\mathrm{Al}_{2} \mathrm{O}_{3}$ & 2.05 & 15.05 & 17.90 & 16.12 & 15.50 & 18.16 & 17.46 & 17.16 & 18.76 & 16.46 & 16.82 & 14.40 & 15.87 & 17.76 & 15.16 & 15.55 \\
\hline $\mathrm{Fe}_{2} \mathrm{O}_{3}$ & 0.22 & 1.00 & 0.71 & 0.59 & 1.01 & 1.24 & 0.34 & 0.12 & 1.35 & 0.95 & 0.15 & 1.42 & 0.83 & 1.02 & 1.81 & 0.83 \\
\hline $\mathrm{FeO}$ & 0.85 & 2.75 & 4.44 & 4.79 & 3.40 & 9.05 & 9.25 & 8.59 & 6.04 & 3.89 & 2.87 & 3.32 & 3.46 & 3.03 & 2.72 & 3.31 \\
\hline $\mathrm{MnO}$ & 0.09 & 0.13 & 0.10 & 0.18 & 0.20 & 0.29 & 0.36 & 0.24 & 0.20 & 0.24 & 0.14 & 0.16 & 0.19 & 0.12 & 0.15 & 0.14 \\
\hline $\mathrm{MgO}$ & 0.62 & 2.35 & 1.88 & 2.80 & 1.90 & 4.09 & 3.74 & 6.03 & 3.03 & 1.47 & 1.48 & 1.71 & 1.17 & 1.45 & 1.31 & 1.81 \\
\hline $\mathrm{CaO}$ & 0.09 & 2.02 & 1.68 & 2.67 & 2.00 & 7.52 & 9.29 & 10.33 & 6.96 & 4.91 & 5.32 & 4.84 & 3.65 & 5.21 & 4.26 & 4.14 \\
\hline $\mathrm{Na}_{2} \mathrm{O}$ & 0.35 & 2.96 & 2.84 & 2.65 & 3.53 & 2.89 & 2.92 & 1.26 & 3.18 & 4.24 & 3.78 & 4.07 & 4.33 & 3.62 & 3.68 & 3.20 \\
\hline $\mathrm{K}_{2} \mathrm{O}$ & 0.87 & 3.55 & 5.16 & 4.08 & 2.49 & 3.24 & 1.48 & 1.48 & 1.48 & 1.55 & 2.30 & 1.97 & 2.35 & 2.25 & 2.90 & 2.99 \\
\hline $\mathrm{H}_{2} \mathrm{O}(+)$ & 1.02 & 2.67 & 2.14 & 2.60 & 2.22 & 1.20 & 1.63 & 1.50 & 1.90 & 2.06 & 0.83 & 1.08 & 1.24 & 1.04 & 1.36 & 1.29 \\
\hline $\mathrm{H}_{2} \mathrm{O}(-)$ & 0.04 & 0.50 & 0.25 & 0.28 & 0.46 & 0.33 & 0.17 & 0.23 & 0.25 & 0.16 & 0.28 & 0.31 & 0.11 & 0.19 & 0.48 & 0.22 \\
\hline $\mathrm{P}_{2} \mathrm{O}_{5}$ & 0.00 & 0.02 & 0.10 & 0.02 & 0.01 & 0.09 & 0.06 & 0.02 & 0.02 & 0.03 & 0.11 & 0.03 & 0.03 & 0.02 & 0.02 & 0.05 \\
\hline Total & 99.53 & 100.32 & 99.51 & 100.48 & 99.53 & 99.26 & 99.10 & 100.14 & 99.98 & 99.94 & 99.62 & 99.55 & 100.14 & 99.61 & 100.25 & 99.45 \\
\hline No. & 17 & 18 & 19 & 20 & 21 & 22 & 23 & 24 & 25 & 26 & 27 & 28 & 29 & 30 & 31 & 32 \\
\hline Specimen & YN 29-1 & YN 4-1 & YN 4-2 & YN 3-3 & OS $7-2$ & YN 15 & YN 8-3 & OS 2-5 & OS 4 & YN 12 & OS 2-2 & OS $2-3$ & YN 11 & OS 6 & YN 6-1 & YN 5-2 \\
\hline $\mathrm{SiO}_{2}$ & 67.02 & 67.80 & 66.70 & 70.19 & 72.09 & .72 .43 & .68 .44 & 71.40 & 73.21 & 68.31 & 88.00 & 82.09 & 71.87 & 67.68 & 73.45 & \begin{tabular}{|l}
73.43 \\
\end{tabular} \\
\hline $\mathrm{TiO}_{2}$ & 0.63 & 0.50 & 0.50 & 0.49 & 0.43 & 0.40 & 0.30 & 0.38 & 0.13 & 0.50 & 0.28 & 0.25 & 0.36 & 0.43 & 0.28 & 0.00 \\
\hline $\mathrm{Al}_{2} \mathrm{O}_{3}$ & 15.18 & 15.91 & 15.96 & 14.81 & 14.55 & 14.18 & 16.36 & 14.59 & 13.87 & 16.68 & 4.56 & 9.01 & 13.96 & 16.09 & 14.38 & 13.54 \\
\hline $\mathrm{Fe}_{2} \mathrm{O}_{3}$ & 0.78 & 1.29 & 1.34 & 0.31 & 0.77 & 0.78 & 0.11 & 0.50 & 0.46 & 0.42 & 0.67 & 0.36 & 0.54 & 0.94 & 0.45 & 0.23 \\
\hline $\mathrm{FeO}$ & 2.69 & 1.95 & 3.10 & 1.69 & 1.51 & 0.99 & 2.62 & 1.34 & 0.74 & 2.36 & 0.84 & 1.08 & 1.65 & 2.69 & 1.11 & 0.12 \\
\hline $\mathrm{MnO}$ & 0.17 & 0.14 & 0.12 & 0.07 & 0.09 & 0.16 & 0.26 & 0.09 & 0.06 & 0.12 & 0.09 & 0.34 & 0.14 & 0.12 & 0.16 & 0.01 \\
\hline $\mathrm{MgO}$ & 1.35 & 0.91 & 0.87 & 0.81 & 0.57 & 0.62 & 0.75 & 0.85 & 0.21 & 0.79 & 0.86 & 0.52 & 0.86 & 0.77 & 0.32 & 0.05 \\
\hline $\mathrm{CaO}$ & 3.85 & 4.42 & 3.95 & 2.62 & 3.93 & 2. 39 & 3.16 & 2.39 & 1.98 & 2.90 & 0.26 & 1.00 & 2.56 & 4.00 & 1.69 & 0.31 \\
\hline $\mathrm{Na}_{2} \mathrm{O}$ & 3.57 & 4.00 & 3.96 & 3.49 & 3.64 & 3.66 & 4.06 & 3.98 & 3.70 & 3.30 & 0.87 & 1.77 & 3.96 & 4.35 & 3.94 & 2.07 \\
\hline $\mathrm{K}_{2} \mathrm{O}$ & 3.33 & 1.86 & 2.20 & 3.65 & 1.63 & 3.91 & 2.02 & 3.36 & 3.70 & 3.80 & 2.07 & 1.37 & 3.37 & 2.36 & 3.85 & 9.31 \\
\hline $\mathrm{H}_{2} \mathrm{O}(+)$ & 1.14 & 1.12 & 1.04 & 0.95 & 0.63 & 0.59 & 1.39 & 0.81 & 1.58 & 0.98 & 0.88 & 1.15 & 0.70 & 0.77 & 0.84 & 0.41 \\
\hline $\mathrm{H}_{2} \mathrm{O}(-)$ & 0.15 & 0.30 & 0.22 & 0.28 & 0.23 & 0.31 & 0.19 & 0.25 & 0.18 & 0.18 & 0.18 & 0.31 & 0.28 & 0.12 & 0.06 & 0.07 \\
\hline $\mathrm{P}_{2} \mathrm{O}_{5}$ & 0.02 & 0.01 & 0.02 & 0.07 & 0.01 & 0.02 & 0.03 & 0.03 & 0.01 & 0.07 & 0.01 & 0.01 & 0.02 & 0.01 & 0.04 & 0.00 \\
\hline Total & 99.88 & 100.21 & 99.98 & 99.43 & 100.08 & 100.44 & 99.69 & 99.97 & 99.83 & 100.41 & 99.57 & 99.26 & 100.27 & 100.33 & 100.57 & 99.55 \\
\hline
\end{tabular}


Major element chemistry of metamorphic and granitic rocks of the Yanai district

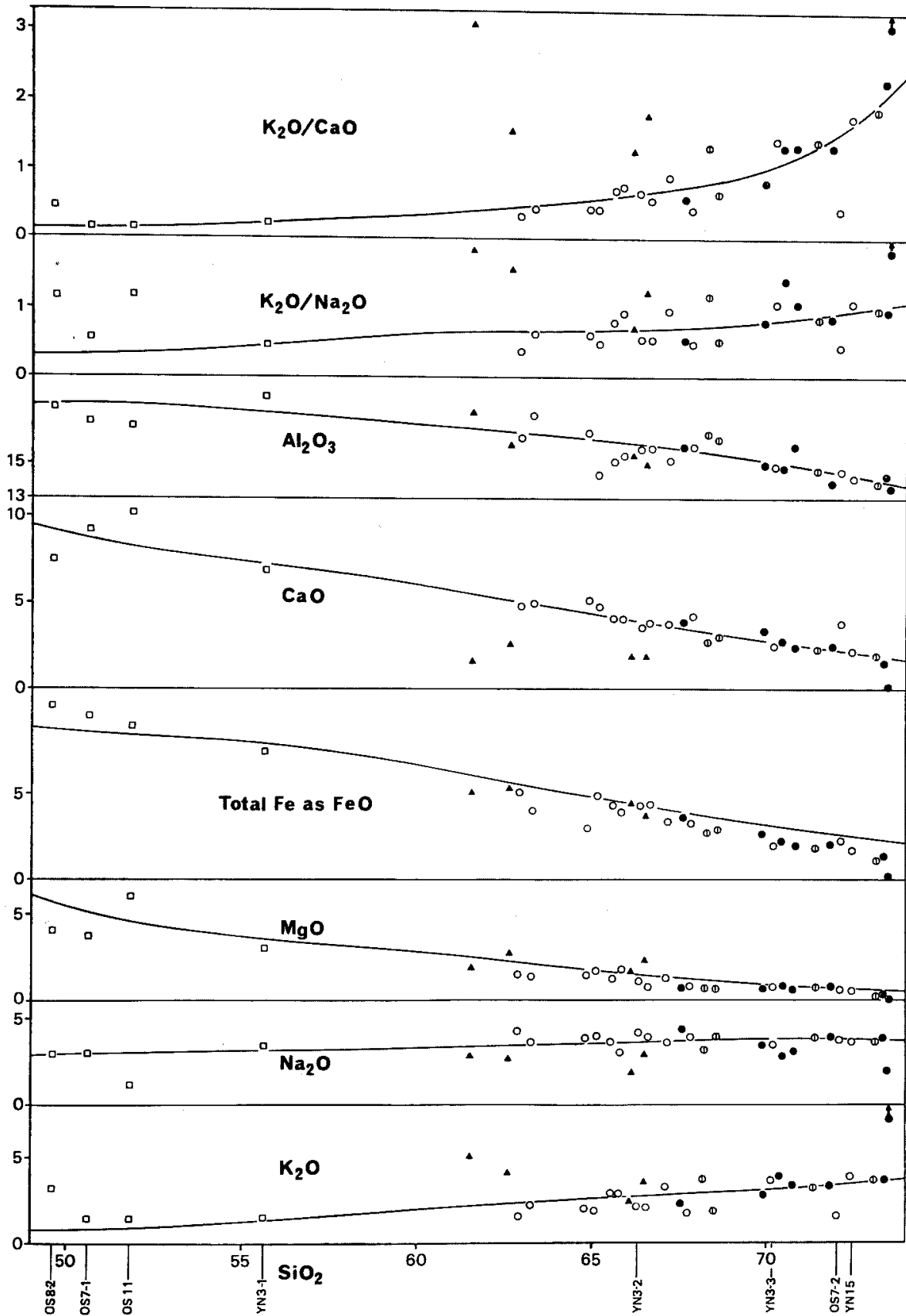

o Gamano layered granodiorite - discordant granite curves: for the average Japanese granitic rocks - Okiura layered granite a amphibolite spelitic gneiss and pelitic hornfels

Figure 2. Variation diagram 
similar to that of a more silica-defficient member of the rocks. This discrepancy is responsible to the formation of porphyroblastic quartz.

The MgO: total iron: total alkalies diagram The $\mathrm{MgO}$ : total iron as $\mathrm{FeO}$ : total alkalies (weight per cent) diagram for the granitic rocks of this district and the younger (discordant) Ryōke granitic rocks of the Kansai district (Shibata et al., 1960), the eastward extension of the Ryōke belt, are shown in Figure 3 (a). The curve for the
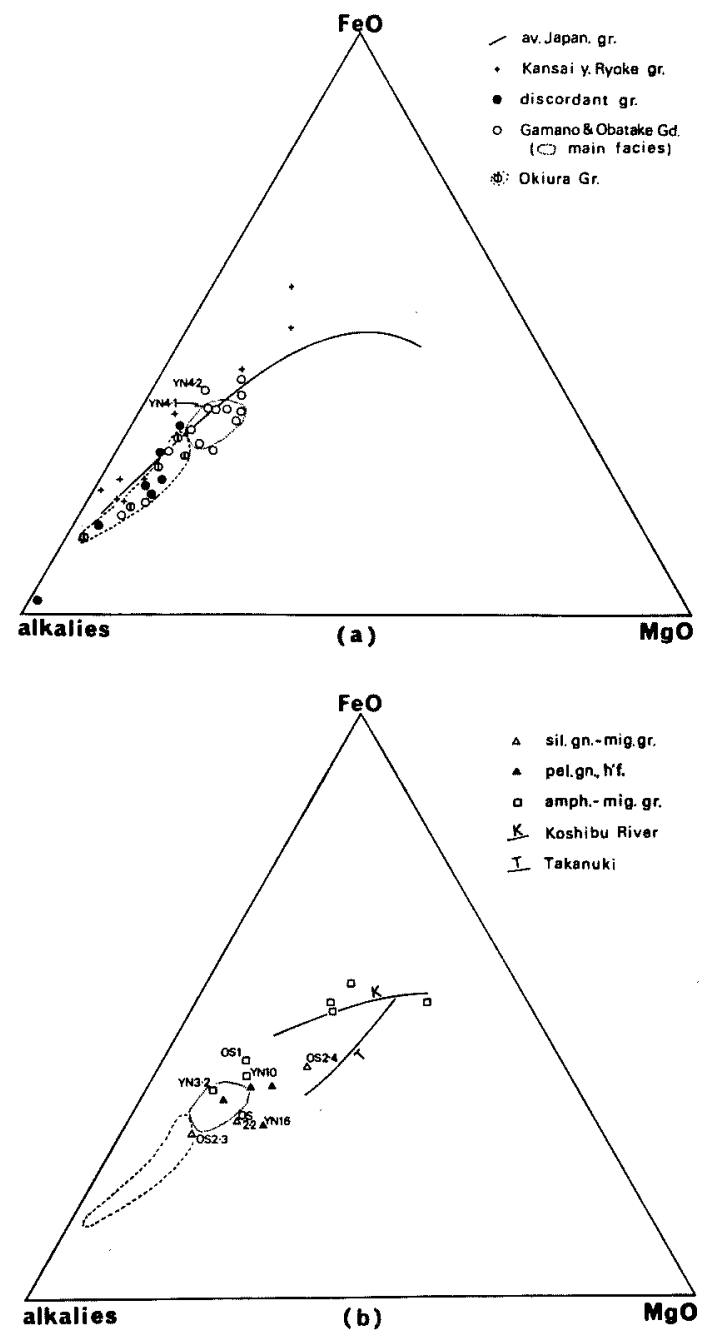

Figure 3. MgO-FeO-alkalies diagram average Japanese granitic rocks (Taneda, 1962) is shown also in this figure. Most of points for the granitic rocks of this district fall in a narrow zone along the MgO-rich side of this curve. This may indicate a close genetical relationship among all the granitic rocks of this district. Among many varieties of the Ryōke granitic rocks in Central Japan (Yamada and Hayama; 1967) the gneissic socalled Tenryükyō granite and allied rocks are most similar to granitic rocks of this district in respect of low $\mathrm{FeO} / \mathrm{MgO}$ in acid facies. On the other hand, the younger Ryōke granitic rocks of the Kansai district are characterized by high $\mathrm{FeO} / \mathrm{MgO}$ and their trend is similar in form to that of the younger Ryōke granitic rocks in Central Japan.

Points for the main facies of the Ōbatake and Gamano layered granodiorites are concentrated in a narrow field clearly separated from that of the Okiura layered granite and the discordant granites. The narrow range of variation in composition of the main facies of the Ōbatake and Gamano layered granodiorites shown in Fig. 2 and Fig. 3 should indicate that they originated from a magma of equivalent composition. Points for migmatitic facies associated with amphibolites are in the alkali-poor field while points for YN3-3, OS7-2 and YN15 fall in the field for the Okiura layered granite and the discordant granites. YN4-2 is from a schlieren rich in biotite in coarsegrained facies of the layered granodiorite (YN4-1).

The MgO: total iron as $\mathrm{FeO}$ : total alkalies (weight per cent) diagram for pelitic metamorphic rocks and siliceous gneiss with its associated granitic rocks are shown in Figure 3 (b). Siliceous gneiss (OS2 -4) and majority of pelitic metamorphic rocks are lower in $\mathrm{FeO} / \mathrm{MgO}$ than granitic 
rocks. A melanocratic part (OS2-2) of a thin migmatitic band of the Okiura layered granite enclosed in siliceous gneiss is characterized also by low $\mathrm{FeO} / \mathrm{MgO}$. There is a need of large chemical changes involving subtraction of $\mathrm{Mg}$ accompanied with addition of alkalies for the metasomatic formation, if it were the case, of the 'Okiura layered granite from sedimentary gneisses.

Amphibolites and some migmatitic facies of the Ōbatake and Gamano layered granodiorites associated with them are also plotted on Fig. 3 (b) with a comparison of the trend of the rock association in the process of granitization of metadiabase in the Ryōke belt in the vicinity of the Koshibu river, Central Japan (Ishii and Yamada, 1962). Both trends show a regular increase in the $\mathrm{FeO} / \mathrm{MgO}$ ratio accompanied with the increase in total alkalies.

In Fig. 3 (b) there is also shown a trend of the rock association formed by the granitization of amphibolite in the Takanuki district in the Abukuma metamorphic belt, Northeast Japan (Ogura, 1956). All the rocks carry nearly constant $\mathrm{FeO} / \mathrm{MgO}$ and the trend is very much different in form from those mentioned above. The trend of this rock association can be interpreted by a simple process of an addition of granitic magma itself or materials rich in alkalies, while the increase in $\mathrm{FeO} / \mathrm{MgO}$ accompanied with increase in alkalies recognized in the rock association in the vicinity of the Koshibu river should be interpreted only by a process involving a subtraction of $\mathrm{MgO}$. In the case of the amphibolite-migmatitic granodiorite association in this district, remarkable changes in chemistry involving $\mathrm{Mg}$ -subtraction accompanied with addition of alkalies have occurred in the rocks which remain granoblastic amphibolite. It must be a reasonable conclusion that an aqueous fluid played an important role in the process mentioned above.

The normative $Q$ : ab: or diagram The normative $Q: a b:$ or (weight per cent) diagram is presented in Figure 4. As the sum of their normative $Q, a b$ and or increases, most points for granitic rocks become concentrated within a narrow field around the curve for isobaric minimum for low water-vapor pressures of Tuttle and Bowen (1958) in the system $\mathrm{NaAlSi}_{3} \mathrm{O}_{8}-\mathrm{KAlSi}_{3} \mathrm{O}_{8}-\mathrm{SiO}_{2}-\mathrm{H}_{2} \mathrm{O}$.

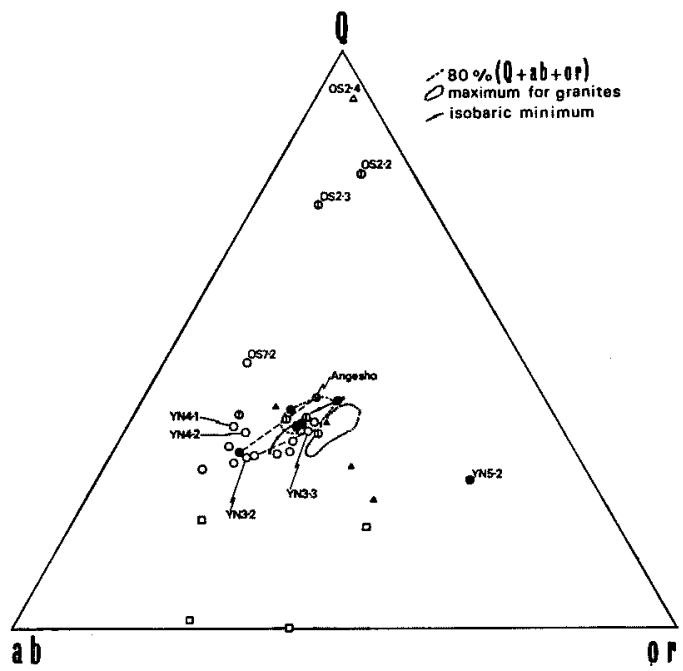

Figure 4. Normative $Q$-ab-or diagram Simbols as in Fig. 2. Angesho: The Towa granite (biotite-granitic facies, Shibata et al., 1960)

Among the points for the Ōbatake and Gamano layered granodiorites, only two (for YN3-3 and YN15) are included in this field. The trend of the metasomatic transition from migmatitic granodiorite (YN3-2) to porphyroblastic $\mathrm{K}$-feldspar-bearing facies (YN3-3) is characterized by a remarkable increase in normative or as well as $Q$. The point for the porphyroblastic quartz-bearing granitic facies (OS7-2) is far from those for the other granitic rocks and should be inter- 
preted by the addition of nearly only silica as mentioned in the preceding paragraph.

A schlieren (YN4-2) is almost identical in this diagram to the enclosing coarsegrained, layered biotite granodiorite (YN41), however, a slight enrichment of or is recognized. Similar relationship between them is also seen in other diagrams and may indicate the formation of the schlieren by accumulation of biotite.

The concentration of all the points for the Okiura layered granite except YN8-3, OS2-2 and OS2-3 within the above field may be interpreted most simply by the assumption that the Okiura layered granite as well as the discordant granites originated from an acid granitic magma. But, on account of the trend of the metasomatic transition from YN3-2 to YN3-3 mentioned above, possibility of essentially metasomatic origin of this granite can not be ruled out. Melanocratic, migmatitic granite (OS2-2) and leucogranite (OS2-3) in thin band in siliceous gneiss (OS2-4), both of which carry 90 per cent or more normative $Q, a b$ and $o r$ are plotted far from the isobaric minimum, however, they have a trend to approach towards the isobaric minimum with decreasing of $(Q+a b+o r)$ contents.

Points for pelitic gneiss are much scattered.

From the fact that an aplite (YN5-2) with 98 per cent $(Q+a b+o r)$ is far from the isobaric minimum in this diagram, the aplite should not have been formed by a simple solidification of the melt of equivalent composition.

The normative $Q:(a b+a n)$ : or diagram The normative $Q:(a b+a n)$ : or (weight per cent) diagram is presented in figure 5 . In this diagram too, most of points for granitic rocks are concentrated in a narrow field.

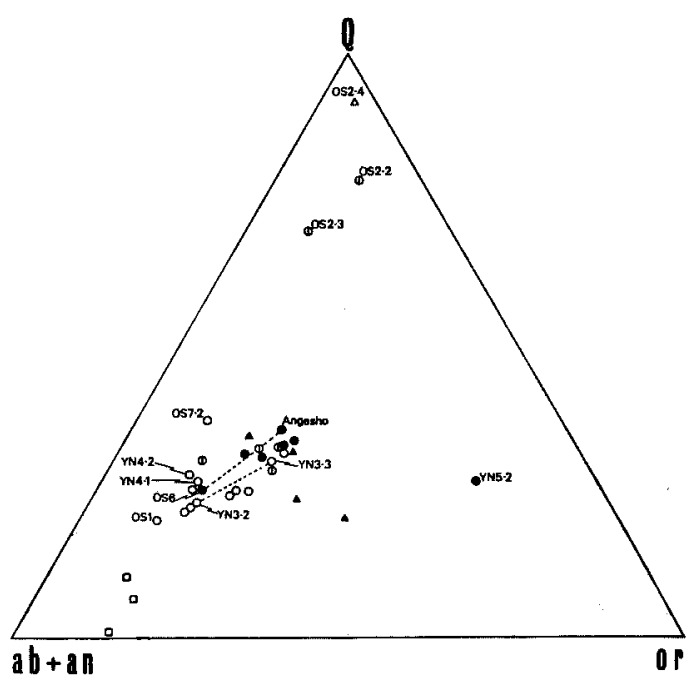

Figure 5. Normative $Q-(a b+a n)$-or diagram Simbols as in Fig. 4

On the contrary to the case in the $Q$ : $a b$ : or diagram, the amphibolites and the Obatake and Gamano layered granodiorites as a whole show a smooth trend in this diagram. The transition from amphibolite to granodiorite is characterized by an increase in $Q$-component and the porphyroblastic quartz-bearing granitic facies (OS72) is plotted on the extension of this trend.

\section{GONGLUDING REMARKS}

Chemical relationships among various rocks of the Yanai district are discussed in this paper.

There are many evidences suggesting that "granitization" in a broad sense took place in this district (Okamura, 1957). However, it is not an utterly accepted conclusion that all portion of granitic rocks in this district were formed through this process. And it should be a question of importance whether granite magma is cause or result in the process of the "granitization" (Aoki, 1964).

It is not the purpose of this paper to 
obtain a decisive proof in connection with this problem and the postulations as follows are not so much conclusive. The narrow range of variation in composition of the main facies of the Ōbatake and Gamano layered granodiorites may suggest that they originated from a magma of equivalent composition. So far as the "sourse" problem is concerned, it must be reasonable to conclude that the granitic material played an important role in the formation of the Okiura layered granite because it differs much in chemistry from amphibolite and sedimentary gneisses. The smooth curve for the main facies of the Ōbatake and Gamano layered granodiorites and the Okiura layered granite as a whole similar in form to that for the average Japanese granitic rocks and the concentration of the latter granite within a narrow field around the curve for isobaric minimum for low water-vapor pressures may indicate an magmatic origin of this granite too. But possibility of essentially metasomatic origin of this granite cannot be ruled out as it was mentioned in the preceding paragraph. Granted that these layered granodiorites and granite were derived from a magma originated in the depths, the "granitization" mentioned above could be regarded as the result of an intense interaction between the granitic magma and surrounding rocks.

A detailed discussion on the inechanism of formation of the granitic socks in this district will be given in succeeding papers on the basis of other geochemical evidences.

\section{ACKNOWLEDGEMENTS}

I wish to express my thanks to Dr. Y. Hayama of Tokyo Nōgyō Daigaku (Tokyō University of Agriculture) for his helpful criticism of an early draft of the manuscript.
My thanks are also due to Dr. K. Nureki of Okayama University for his valuable suggestion.

The analytical work was carried out by Mrs. K. Ikehara and Mrs. Fukui of this institute. I am indebted also to Mrs. H. Yamawaku and Mr. H. Asada of this institute for their technical assistance.

This work has been supported by Grant in Aid for Scientific Research from the Ministry of Education of Japan (Assoc. Prof. M. Gorai: "The Origin and Evolution of Acid Magmas").

\section{REFERENGES}

Aoki, H. (1964), Short history of granite controversy. Research and Review (Jow. Hosei 2-ko). No. 11, 1-16.

Ishii, M. and Yamada, T. (1962), On the granitization of metadiabase in the vicinities of the Koshibu river, Nagano Prefecture, Central Japan. Jour. Geol. Soc. Japan, 68, 109-117 (in Japanese).

Iwao, S. (1936), The field relations between granites and Ryōke metamorphics in the Yanai District, Yamaguchi Prefecture. Jour. Geol. Soc. Japan, 43, 660-691 (in Japanese).

Kojima, G. (1953), Contribution to the knowledge of mutual relations between three metamorphic zones of Chūgoku and Shikoku, Southwestern Japan, with special reference to the metamorphic and structural features of each metamorphic zone. Jour. Sci. Hiroshima Univ., Ser., $C, 1,17-44$.

Kojima, G. and Okamura, Y. (1968). On the Kitaöshima granite gneiss complex. Jour. Sci. Hiroshima Univ., Ser. C, 5, 295-306.

Nozawa, T. (1970), Isotopic ages of Late Cretaceous acid rocks in Japanese Islands; Summary and notes in 1970. Jour. Geol. Soc. Japan, 76, 493-518 (in Japanese).

Nureki, T. (1960), Structural investigation of the Ryōke metamorphic rocks of the area between Iwakuni and Yanai, Southwestern Japan. Jour. Sci. Hiroshima Univ., Ser. C, 3, 69-141.

Ogura, Y. (1956), On the granitization of amphibolite from the Takanuki district, Southern Abukuma Plateau. Jour. Geol. Soc. Japan, 62, 609-621 (in Japanese).

Okamura, Y. (1957), Structure of the Ryöke metamorphic and granodioritic rocks of the Yanai 
district, Yamaguchi Prefecture. Jour. Geol. Soc. Japan, 63, 684-697 (in Japanese). (1960), Structural and petrological studies on the Ryōke gneiss and granodiorite complex of the Yanai district, Southwest Japan. Jour. Sci. Hiroshima Univ., Ser. C, 3, 143-213. and Nureki, T. (1962), The Ryōke metamorphic belt at the Yanai district. Guidebook of the excursion at the Meeting of Nihon Chigaku Kyoiku-Kenkyü-kai (in Japanese).

Ōki, Y. et al. (1962), The systematic analysis of silicate rocks using ion exchange resin. Bull. Chem. Soc. Japan, 35, 274-276.

Read, H.H. (1949), A contemplation of time in plutonism. Quart. Jour. Geol. Soc. London, 105, 101-105.

Shibata, H. et al. (1960), Chemical composition of Japanese granitic rocks in regard to petrographic provinces. Part VII. Sci. Rep. Tokyo Kyoiku Daigaku, Sec. C, 5, 1-23.

Taneda, S. (1962), Chemical compositions of granitic and volcanic rocks in Japan. Jour. Geol. Soc. Japan, 68, 118-124 (in Japanese).

Toyohara, F. (1974), On the age of the Kuga group and Ryōke metamorphic rocks in eastern Yamaguchi Prefecture. Jour. Geol. Soc. Japan, 80, 51-53 (in Japanese).

Tuttle, C.F. and Bowen, N.L. (1958), Origin of granite in the light of experimental studies in the system $\mathrm{NaAlSi}_{3} \mathrm{O}_{8}-\mathrm{KAlSi}_{3} \mathrm{O}_{8}-\mathrm{SiO}_{2}-\mathrm{H}_{2} \mathrm{O}$. Geol. Soc. Amer. Mem. 74.

Yamada, T. and Hayama, Y. (1967), Some considerations on the chemical composition of the Ryōke granitic rocks in Central Japan. Prof. H. Shibata Mem. Vol., 113-118 (in Japanese).

Appendix A Brief Description of Rocks Analyzed

Siliceous gneiss

1. OS2-4 Rather massive siliceous gneiss derived from banded chert, muscovite -biotite-quartz.

Pelitic metamorphic rocks

2. YN16 Low-grade garnet-mica hornfels. Pelitic and somewhat psammitic layers are finely alternated.

3. YN38 Pelitic gneiss with ptigmatic Kfeldspar-plagioclase-quartz veins, cordierite - muscovite - biotite- $\mathrm{K}$ - feldsparplagioclase-quartz.

4. YN28 Coarse-grained pelitic gneiss with ptigmatic K-feldspar veins, sillimanitecordierite-muscovite-K-feldspar-quartz.

5. OS2-1 Partly migmatitic pelitic gneiss intercalated in siliceous gneiss (OS2 4), sillimanite-cordierite-muscovite-Kfeldspar-plagioclase-quartz. Garnet occurs in siliceous bands.

\section{Amphibolites}

6. OS8-2 Remnants of amphibolite in small patch scattered layerly in coarsegrained migmatitic biotite granite, OS8 -1 , with whom constituting a marginal part of an agmatitic mass.

7. OS7-1 Medium-grained, granoblastic amphibolite in an agmatitic mass surrounded by porphyroblastic quartzbearing biotite granite (OS7-2). Much the same as OS11, but $\mathrm{K}$-feldspar is absent.

8. OS11 Medium-grained, granoblastic amphibolite in an agmatitic mass, hornblende - biotite - K-feldspar - plagioclase-quartz-magnetite-ilmenite.

9. YN3-1 Granoblastic amphibolite with poikilitic biotite in an irregular xenolith-like block enclosed in migmatitic granodiorite (YN3-2). The mineral assemblage is the same to that of OS11.

The Obatake and Gamano layered granodiorites

10. OS1 Migmatitic, hornblende-biotite granodiorite with zoned phenoblasts of plagioclase. Enclosing many blocks of basic remnants.

11. OS8-1 Foliated, coarse-grained, migmatitic, biotite granodiorite. A leucosome associated with amphibolite paleosome.

12. YN10 Gneissose, fine-grained, migmatitic, hornblende-biotite granodiorite, characterized by a remarkable fine gneissosity with advanced lineation. The Gokenya granodiorite of Okamura 
(1957).

13. YN3-2 Medium- and equi-granular migmatitic biotite granodiorite with many blocks of basic remnants.

14. OS10-2 Foliated, coarse-grained biotite granodiorite, surrounded by medium-grained migmatitic biotite granite. Granite gneiss of Kojima and Okamura (1968).

15. YN30 Foliated, coarse-grained hornblende-biotite granodiorite with relic diopsidic pyroxene. Including many xenolith-like blocks and nebulites with foliation parallel to that of the host granodiorite.

16. YN9-1 Foliated, coarse-grained granodiorite with relic diopsidic pyroxene, enclosing many basic patches (up to $4 \times 10 \mathrm{~cm}$ ), in large hornblende-biotite granodiorite mass.

17. YN29-1 Foliated, coarse-grained hornblende-biotite granodiorite in large and homogeneous mass.

18. YN4-1 Foliated, coarse-grained biotite granodiorite in rather homogeneous large mass.

19. YN4-2 Nebulitic schlieren slightly rich in biotite, enclosed in coarse-grained biotite granodiorite, YN4-1.

20. YN3-3 A granitic facies developed in the migmatitic biotite granodiorite, $\mathrm{YN}$ 3-2, with much amounts of large (up to $1.5 \times 5 \mathrm{~cm}$ ) euhedral porphyroblasts of $\mathrm{K}$-feldspar.

21. OS7-2 Medium-grained, gneissose, migmatitic, biotite granite with porphyroblastic large crystals of quartz.

22. YN15 Weakly foliated, medium-grained, garnet-bearing, intrusive leucogranite in rather homogeneous mass, intimately associated with the Obatake and Gamano layered granodiorites.

\section{The Okiura layered granite}

23. YN8-3 Foliated, medium-grained, garnet-bearing, two-mica granite, garnetbiotite - muscovite - plagioclase - quartz. K-feldspar rarely occurs. Alternates with thick layers of siliceous banded gneiss.

24. OS2-5 Foliated, leucocratic, mediumgrained, migmatitic biotite granite in rather homogeneous mass. Some thin bands of remnants of siliceous gneiss are included.

25. OS4 Much the same as OS2-5.

26. YN12 Foliated, fine-grained, migmatitic biotite granite. Many thin siliceous bands and biotite-rich ones are included.

27. OS2-2 Medium-grained, migmatitic, two-mica granite, in thin melanocratic band rich in quartz and biotite, enclosed in OS2-3.

28. OS2-3 Medium-grained, garnet-bearing, two-mica leucogranite, occurring in layer, 10 to $30 \mathrm{~cm}$ in thickness, in siliceous gneiss (OS2-4). The shape of the mass is largely concordant to the structure of the enclosing gneiss.

The discordant granites

29. YN11 Massive medium-grained, twomica granite, the Murotsiu granite of Okamura (1957).

30. OS6 Weakly foliated, much coarsegrained, hornblende-biotite granodiorite, the Tōwa granodiorite of Okamura (1957).

31. YN6 Gneissose, fine-grained, two-mica granite in rather homogeneous mass, intruding into the Ōbatake and Gamano layered granodiorites.

32. YN5-2 Fine-grained, two-mica aplite in vein in fine-grained two-mica granite (YN6). 


\section{柳井地方領家帯の变成岩および花崗岩類の主化学組成}

柳井地方領家帯に出現する，岡村（1957）に略従って区分された花崗岩類および变成岩類 32 試料の主化学成 分を分析し，幾つかの図を中心に，これら岩石の化学的相関性を示した。花崗岩類と，角閅岩・堆皘岩源変成岩 との間には，化学的に多くの点で著るしい相違が見られる。大香, 蒲野層状花岡閃緑岩の主要相を代表すると見

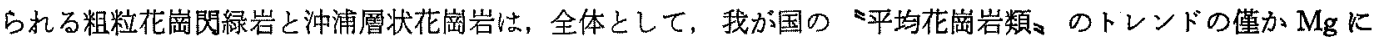
富む側に沿って，スムースな組成変化を示す。前者は，狭い組成頒域に集中し，これより酸性な後者とは明嘹に 分かたれる。また沖浦層状花岡岩は，Q-ab-or 図で，最低上う融点付近に集中寸る。これらの主化学組成の特街 は, これら凮状花崗岩類がマグマ起源のものと考えることによって最も単純に説明されると思われるが,一方で

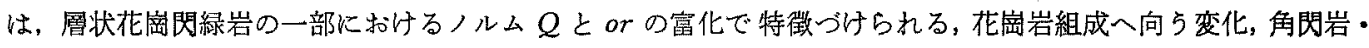
けい質片麻岩におけるアルカリの增加にとむなら $\mathrm{Mg}$ の除去を特垷とする変化などに代表される交代作用の存 在る明らかである。

Angeshō 安下庄 Gamano 蒲野 Gokenya 五軒屋 Kibe 木部 Kuga 玫玚

Murotsu 室津 Obatake 大香 Okiura 沖浦 Tōwa 東和 Yanai 柳井 